\title{
The Proton Affinity of Proline Analogs Using the Kinetic Method with Full Entropy Analysis
}

\author{
Andrew F. Kuntz, Andrew W. Boynton, Geoffrey A. David, \\ Kathryn E. Colyer, and John C. Poutsma \\ Department of Chemistry, The College of William and Mary, Williamsburg, Virginia, USA
}

The proton affinity of proline analogs, L-azetidine-2-carboxylic acid (Aze), L-proline (Pro), and L-pipecolic acid (Pip), have been measured using the Armentrout modification of the extended kinetic method in a quadrupole ion trap instrument. Experimental values of $223.0 \pm 1.5$, $224.9 \pm 1.6$, and $225.6 \pm 1.6 \mathrm{kcal} / \mathrm{mol}$ have been determined for the $298 \mathrm{~K}$ proton affinities of Aze, Pro, and Pip respectively. High level theoretical calculations using both MP2 and B3LYP methods at a variety of basis sets were carried out in order to give theoretical predictions for the $298 \mathrm{~K}$ proton affinity and gas phase basicity of all three analogs. Recommended values for the gas phase basicity and proton affinity for proline based on our work and other recent determinations are $216 \pm 2$ and $224 \pm 2 \mathrm{kcal} / \mathrm{mol}$. (J Am Soc Mass Spectrom 2002, 13, 72-81) (c) 2002 American Society for Mass Spectrometry

$\mathrm{A}$ $\mathrm{s}$ the molecular building blocks of proteins and peptides, amino acids have been the subjects of great interest and study. We are interested in how subtle changes in molecular structure influence the thermochemical properties of amino acids. Specifically, we are interested in the thermochemical properties of non-protein amino acids (NPAA), which are naturallyoccurring amino acids that are not used by humans for protein synthesis. NPAAs are ubiquitous in nature and serve a variety of purposes including nitrogen storage and defense [1, 2]. Some NPAAs are structurally similar to one or more of the protein amino acids and as such can be toxic to humans [3]. NPAAs have been shown to misincorporate into peptides and proteins [4-6] and can compete with their PAA analogs in a variety of biological functions [7-9].

The proline analogs, L-azetidine-2-carboxylic acid (Aze, 1), L-proline (Pro, 2), and L-pipecolic acid (Pip, 3) have been studied in solution [10-15] and by molecular mechanics [16-19].

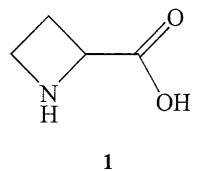

1

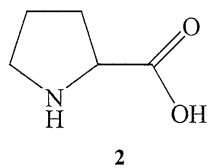

2

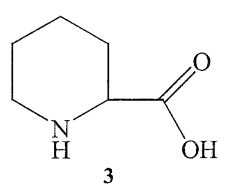

a selective inhibitor [11]. As an initial study of the thermochemical properties of NPAAs, we have determined the proton affinity of 1-3 using the extended kinetic method in a quadrupole ion trap instrument.

Since its introduction into the field of mass spectrometry, the kinetic method has been used extensively to determine thermochemical properties for a variety of molecules [24-31]. The kinetic method is based on the competitive decomposition of ion-bound dimers by either metastable decomposition or collision-induced dissociation. For example, the ratio of the intensities of $\mathrm{AH}^{+}$and $\mathrm{BH}^{+}$from decomposition of the protonbound dimer $\left[\mathrm{AH}^{+} \mathrm{B}\right]$ can be related to the difference in gas-phase basicity (GB), the negative free energy of protonation, between A and B. In early studies using the kinetic method, entropy effects were assumed to be negligible as long as the structures of $\mathrm{A}$ and $\mathrm{B}$ were similar [25]. Provided that this requirement was met, it was assumed that the kinetic method was sensitive to differences in proton affinity (PA), the negative enthalpy of protonation, rather than gas-phase basicity.

In the mid-90's, Fenselau and co-workers $[27,30]$ and Wesdemiotis and co-workers [31] introduced methods to take into account the entropy of dissociation, by performing dissociations at different activation energies. Recently, Armentrout [32] has shown that the approach of Fenselau and Wesdemiotis should be modified in order to eliminate correlation between the variables used to determine the entropy (vide infra).

This work describes the determination of the proton affinities of the proline analogs using the kinetic method with full entropy analysis as well as from high level $\mathrm{ab}$ initio and density functional theory calculations. This is the first determination of any kind for the gas-phase thermochemical properties of Aze or Pip. In addition, we have reviewed the literature and present

Published online November 27, 2001

Address reprint requests to Dr. J. C. Poutsma, Department of Chemistry, The College of William and Mary, P.O. Box 8795, Williamsburg, VA 23187-8795, USA. E-mail: jcpout@wm.edu 
recommended values for the gas phase basicity and proton affinity of proline.

\section{Experimental}

All experiments were performed in a commercial ion trap mass spectrometer (LCQ-DECA, Finnigan MAT, San Jose, CA) equipped with an external electrospray ionization source. For MS experiments, an ion accumulation time of $50 \mathrm{~ms}$ was used. This was increased to 100 $\mathrm{ms}$ for $\mathrm{MS}^{2}$ experiments. ESI and ion focussing conditions were varied in order to optimize the signal of proton-bound dimer ions $\mathrm{AHB}_{i}^{+}$. The heated capillary temperature was kept in the range of $100-175^{\circ} \mathrm{C}$ in order to maximize dimer formation. Dilute solutions $\left(10^{-4}-10^{-5} \mathrm{M}\right)$ of a proline analog and a reference base in acidified (1\% acetic acid) 50:50 $\mathrm{H}_{2} \mathrm{O}: \mathrm{CH}_{3} \mathrm{OH}$ were directly infused into the mass spectrometer at flow rates of 5-20 $\mu \mathrm{L} / \mathrm{min}$. The proton-bound dimer ion $\mathrm{AHB}_{\mathrm{i}}^{+}$ was isolated in the first stage of mass spectrometry at $q_{\mathrm{z}}=0.250$ with isolation widths of $4-5 \mathrm{a} \mu$. The isolation width was adjusted to maximize ion signal while still maintaining ion isolation.

The proton-bound dimer ions were allowed to undergo collision-induced dissociation with the helium buffer gas at varying activation energies. For these studies, an activation time of $30 \mathrm{~ms}$ and activation amplitudes of $15 \%, 50 \%$, and $85 \%\left(3,10\right.$, and $\left.17 \mathrm{~V}_{(\mathrm{p}-\mathrm{p}, \mathrm{Lab})}\right)$ were used. Total ion intensities for the protonated proline analog and protonated reference base products were obtained from signal averaging 40 scans. Proton affinities and activation entropies for each proline analog were obtained using Armentrout's [32] recent modification of the methods of Wesdemiotis and Fenselau $[27,31]$. We used a slightly modified method in which the least-square-fit to the data for the initial plot (plot 1 as described in the following paragraph) is done without the inclusion of the uncertainties in the ratios and proton affinities.

In order to determine the PA and activation entropy from the kinetic method experiment, two plots are needed. The first plot (plot 1 ) is of the natural log of the ratio of product ion intensities from collision-induced dissociation of the proton-bound dimer, $\operatorname{Ln}\left[\mathrm{AH}^{+} /\right.$ $\left.\mathrm{B}_{i} \mathrm{H}^{+}\right]$, versus $\mathrm{PA}\left(\mathrm{B}_{i}\right)-\mathrm{PA}_{\text {avg, }}$ where $\mathrm{PA}\left(\mathrm{B}_{i}\right)$ is the proton affinity of the reference base and $\mathrm{PA}_{\mathrm{avg}}$ is the average proton affinity of the set of reference bases used in the determination. The best-fit line to these data obtained from standard regression techniques has a slope of $-1 / \mathrm{RT}_{\text {eff }}$ and intercept of $\left\{\left[\mathrm{PA}(\mathrm{A})-\mathrm{PA}_{\mathrm{avg}}\right]-\right.$ $\mathrm{T} \Delta \Delta \mathrm{S}\} / \mathrm{RT}_{\text {eff, }}$ where $\Delta \Delta \mathrm{S}$ is the average difference in activation entropy between the proline analog channel and the reference base channel. The $x$-intercept of this best-fit line corresponds to an effective proton affinity in which entropy effects are ignored.

Data is collected at several different activation energies, allowing the contributions of enthalpy and entropy to be separated. The intercepts of the best-fit lines from plot 1 are plotted in a second plot (plot 2) against the negative slope of those lines for the different activation energies. The quantity $\left[\mathrm{PA}(\mathrm{A})-\mathrm{PA}_{\mathrm{avg}}\right]$ is obtained from the slope of the best-fit line to the data in plot 2, whereas the $y$-intercept of this line is $-\Delta \Delta S / R$.

\section{Computational Methods}

Proton affinities for Aze, Pro, and Pip were calculated using $a b$ initio and density functional methods using the Gaussian 98W suite of programs [33]. For this study, we used Hartree-Fock [34], Møller-Plesset perturbation theory [34], and hybrid density functional theory (DFT) methods [35]. The B3LYP method comprises the Becke-3 parameter exchange functional $[36,37]$ and the correlation functional of Lee, Yang and Parr [38]. Optimized geometries, total electronic energies, and harmonic vibrational frequencies for the three amino acids in both their neutral and protonated forms were determined at the following levels of theory: $\mathrm{HF} / 6-31 \mathrm{G}^{*}$, $\mathrm{MP} 2 / 6-31 \mathrm{G}^{*}, \mathrm{~B} 3 \mathrm{LYP} / 6-31 \mathrm{G}^{*}$, B3LYP $/ 6-31+\mathrm{G}^{*}$, and B3LYP $/ 6-311+G^{*}$. In addition, Aze and $\mathrm{AzeH}^{+}$were examined at the MP2/6-31+ $\mathrm{G}^{*}$ and MP2/6-311+ $\mathrm{G}^{*}$ levels. For the neutral species, we only investigated canonical structures; that is, zwitterionic forms were not investigated. All structures were verified to be minima by the absence of negative Eigenvalues in the Hessian matrix. Zero-point energy and thermal corrections were obtained from scaled harmonic frequencies. Scaling factors varied with method as recommended by Scott and Radom [39]. Total entropies for all species were also computed. The translational and rotational contributions to the entropy were taken directly from the calculation output, whereas the vibrational contribution was obtained from scaled vibrational frequencies.

\section{Materials}

All chemicals were obtained from commercial sources and were used as received. Pipecolic acid and azetidine2-carboxylic acid were obtained from Sigma (St. Louis, MO). He purity was $99.99 \%$.

\section{Results}

\section{Experimental Results}

Proton-bound dimers of Aze and a suitable reference base were generated using electrospray ionization from dilute solutions of the two bases in slightly acidified ( $1 \%$ acetic acid) water:methanol solutions. The following reference bases were used: n-butyl amine, i-propyl amine, benzyl amine, pyridine, and c-hexyl amine. Plots of $\ln \left[\mathrm{AH}^{+} / \mathrm{B}_{i}^{+}\right]$versus $\mathrm{PA}\left(\mathrm{B}_{i}\right)-\mathrm{PA}_{\text {avg }}$ at three different activation energies are shown in Figure 1.

The proton affinities for the reference bases are shown in Table 1. For all three analogs, we used the recommended values from the compilation of Hunter and Lias [40] for all reference bases except benzyl 


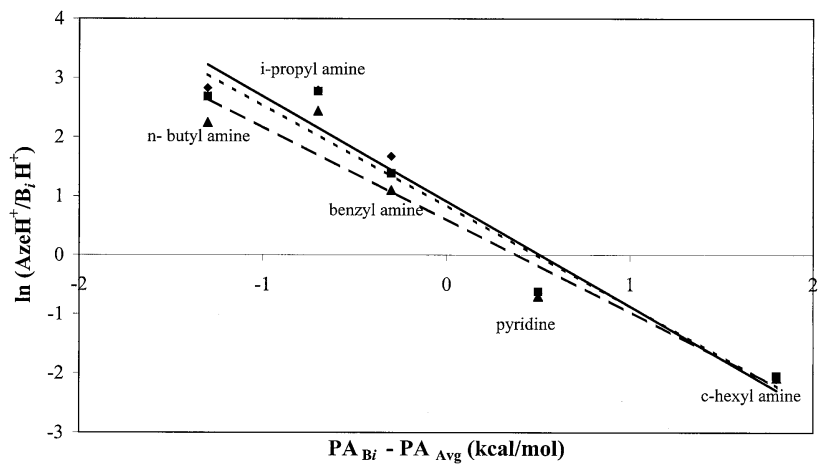

Figure 1. Plot of $\operatorname{Ln}\left[\mathrm{AzeH}^{+} / \mathrm{B}_{i} \mathrm{H}^{+}\right]$versus $\mathrm{PA}\left(\mathrm{B}_{i}\right)-\mathrm{PA}_{\text {avg }}$ at three different activation energies with best-fit lines. (Filled diamond, single line) $3 \mathrm{~V}$, (filled square, short-dashed line) $10 \mathrm{~V}$, and (filled triangle, long-dashed line) $17.5 \mathrm{~V}$ lab.

amine. The compilation lists two primary references for the gas phase basicity for benzyl amine, $210.2 \mathrm{kcal} / \mathrm{mol}$ from Taft [41], and $213.4 \mathrm{kcal} / \mathrm{mol}$ from Aue and Bowers [42] with the Taft measurement as the recommended value. Based on our measured ratios (see Figure 1), benzyl amine should be more basic than both i-propyl amine and n-butyl amine. Taft's value for the proton affinity of benzyl amine $(218.2 \mathrm{kcal} / \mathrm{mol})$ is clearly too low. We therefore used the value of Aue and Bowers of $221.2 \mathrm{kcal} / \mathrm{mol}$ for the proton affinity of benzyl amine.

The $x$-intercepts of the lines shown in Figure 1 correspond to apparent proton affinities for Aze in which entropy effects are ignored. An average of $222.0 \mathrm{kcal} / \mathrm{mol}$ is obtained from these data for the apparent proton affinity for Aze. Figure 2 shows a plot of the intercepts of the three lines from Figure 1 versus the negative of slopes of those lines. The slope of the best-fit line to these data is $1.5 \pm 0.2 \mathrm{kcal} / \mathrm{mol}$, which, when combined with the average proton affinity of the reference base set $(221.5 \pm 1.5 \mathrm{kcal} / \mathrm{mol})$, gives the final value of $223.0 \pm$ $1.5 \mathrm{kcal} / \mathrm{mol}$ for the proton affinity of Aze.

The final uncertainty for the proton affinity is determined from the root sum square of the uncertainties in the slope of plot 2 and the uncertainty in the average proton affinity of the reference base set. The uncertainty in the average proton affinity is composed of the relative error in the measured quantities and a systematic error in

Table 1. Proton affinity of reference bases $(\mathrm{kcal} / \mathrm{mol})$

\begin{tabular}{lcc}
\hline Base & Proton affinity & reference \\
\hline \hline n- $\mathrm{C}_{4} \mathrm{H}_{9} \mathrm{NH}_{2}$ & 220.2 & a \\
$\mathrm{i}-\mathrm{C}_{3} \mathrm{H}_{7} \mathrm{NH}_{2}$ & 220.8 & a \\
$\mathrm{C}_{6} \mathrm{H}_{5} \mathrm{CH}_{2} \mathrm{NH}_{2}$ & 221.2 & b \\
pyridine & 222.0 & a \\
c- $\mathrm{C}_{6} \mathrm{H}_{11} \mathrm{NH}_{2}$ & 223.3 & a \\
3-methyl-pyridine & 225.5 & a \\
4-vinyl-pyridine & 225.6 & a \\
4-methyl-pyridine & 226.4 & a \\
\hline
\end{tabular}

aData from Lias compilation, reference [40]. ${ }^{b}$ Data from reference [42].

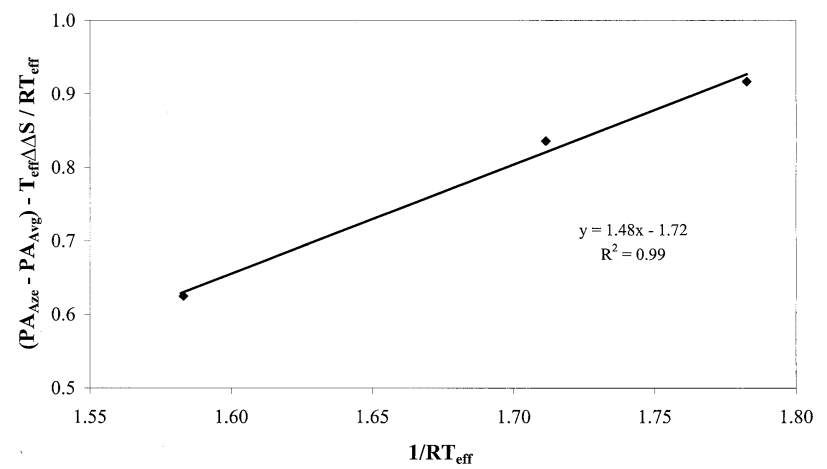

Figure 2. Plot $\left[\left(\mathrm{PA}_{\mathrm{Aze}}-\mathrm{PA}_{\text {avg }}\right)-\mathrm{T}_{\text {eff }} \Delta \Delta \mathrm{S}\right] / \mathrm{RT}_{\text {eff }}$ versus $1 / \mathrm{RT}_{\text {eff }}$ for azetidine-2-COOH.

the absolute proton affinity scale. We assign values of $\sqrt{ } 2$ for the systematic error in the absolute PA scale and $\sqrt{ } 2 / \sqrt{ } N$ for the random error, where $N$ is the number of measurements. In this case, $N$ is 5 , and the total uncertainty in $\mathrm{PA}_{\mathrm{avg}}$ is the root sum square of the random and systematic uncertainties, or $1.5 \mathrm{kcal} / \mathrm{mol}$. Combining this with the uncertainty in the slope of plot $2(0.2$ $\mathrm{kcal} / \mathrm{mol}$ ) gives the final uncertainty in the PA of $\mathbf{1}$.

Similar experiments were performed in order to redetermine the proton affinity of proline. The following reference bases were used: pyridine, c-hexyl amine, 3-methyl pyridine, and 4-methyl pyridine. The proton affinities for the reference bases are given in Table 1. Figure 3 shows plots of $\ln \left[\mathrm{ProH}^{+} / \mathrm{B}_{i} \mathrm{H}^{+}\right]$versus $\mathrm{PA}\left(\mathrm{B}_{i}\right)-\mathrm{PA}_{\mathrm{avg}}$, where $\mathrm{PA}_{\mathrm{avg}}$ for this reference base set is $224.3 \pm 1.6 \mathrm{kcal} / \mathrm{mol}$. Figure 4 shows plot 2 for the proline study. An average PA, in which entropy effects are ignored, of 224.2 is obtained from the x-intercepts of the best-fit lines from plot 1 . The best-fit line to the data shown in Figure 4 has a slope of $0.6 \pm 0.2 \mathrm{kcal} / \mathrm{mol}$, which leads to a final proton affinity for proline of $224.9 \pm 1.6 \mathrm{kcal} / \mathrm{mol}$.

Proton-bound dimer ions of pipecolic acid and the following reference bases were investigated using the techniques described above: c-hexyl amine, 3-methyl pyridine, 4-vinyl pyridine, and 4-methyl pyridine. The proton affinities for these compounds are listed in Table

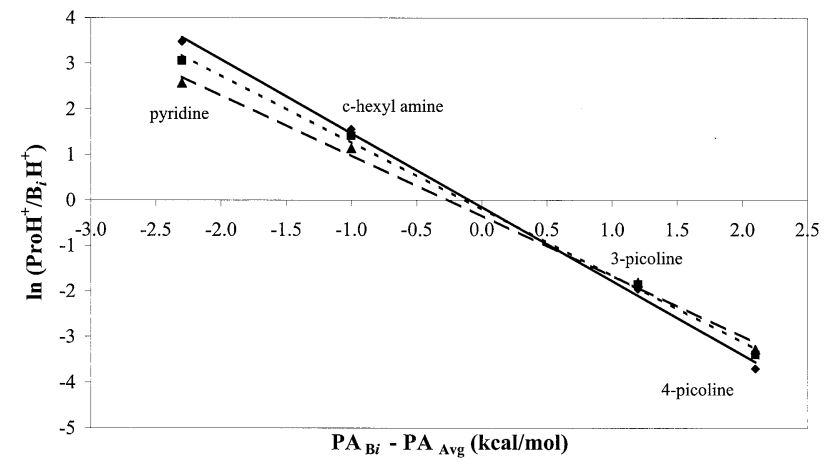

Figure 3. Plot of $\ln \left[\mathrm{ProH}^{+} / \mathrm{B}_{i} \mathrm{H}^{+}\right]$versus $\mathrm{PA}\left(\mathrm{B}_{i}\right)-\mathrm{PA}_{\text {avg }}$ at three different activation energies with best-fit lines. (Filled diamond, single line) $3 \mathrm{~V}$, (filled square, short-dashed line) $10 \mathrm{~V}$, and (filled triangle, long-dashed line) $17.5 \mathrm{~V}$ lab. 


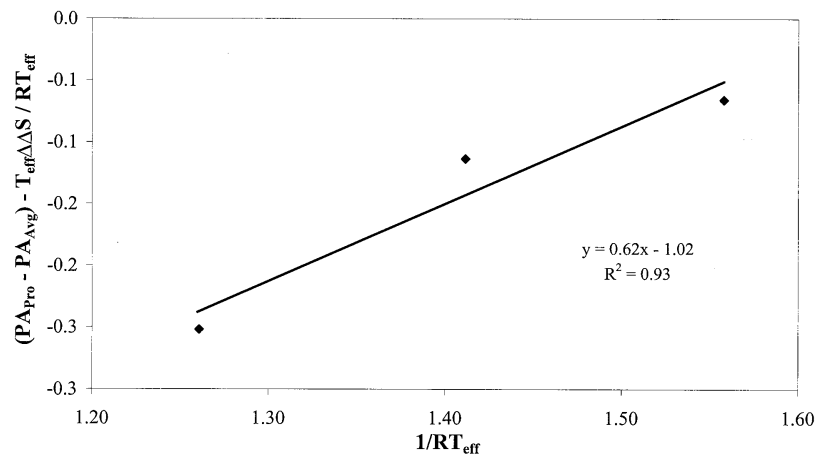

Figure 4. Plot $\left[\left(\mathrm{PA}_{\text {Pro }}-\mathrm{PA}_{\mathrm{avg}}\right)-\mathrm{T}_{\text {eff }} \Delta \Delta \mathrm{S}\right] / \mathrm{RT}_{\text {eff }}$ versus $1 / \mathrm{RT}_{\text {eff }}$ for proline.

1. Figure 5 shows the kinetic method plots for three different activation energies. An apparent proton affinity of 225.3 for pipecolic acid, neglecting entropy effects, is derived from these data. Figure 6 shows the entropy work-up for pipecolic acid from which a final proton affinity of $225.6 \pm 1.6 \mathrm{kcal} / \mathrm{mol}$ is obtained. The uncertainty is the sum of the contributions of the uncertainty in the average PA of the reference base set $( \pm 1.6$ $\mathrm{kcal} / \mathrm{mol})$ and the uncertainty in the slope $( \pm 0.1$ $\mathrm{kcal} / \mathrm{mol})$.

\section{Computational Results}

Several low-lying conformers of Aze were examined using HF, MP, and B3LYP methods. Total electronic energies, scaled ZPEs, 298K enthalpies, and absolute entropies for Aze at various levels of theory are given in Table 2. The two lowest energy structures both involve some hydrogen bonding between (I) the hydroxyl hydrogen and the nitrogen atom and (II) the amino hydrogen and the carbonyl oxygen. Figure 7 shows representative structures at the B3LYP $/ 6-311+\mathrm{G}^{*}$ level of theory. The relative stability of these two conformers differs depending on which method/basis set is used as shown in Table 2. Protonated Aze was also examined at the levels described above. A structure with a hydrogen

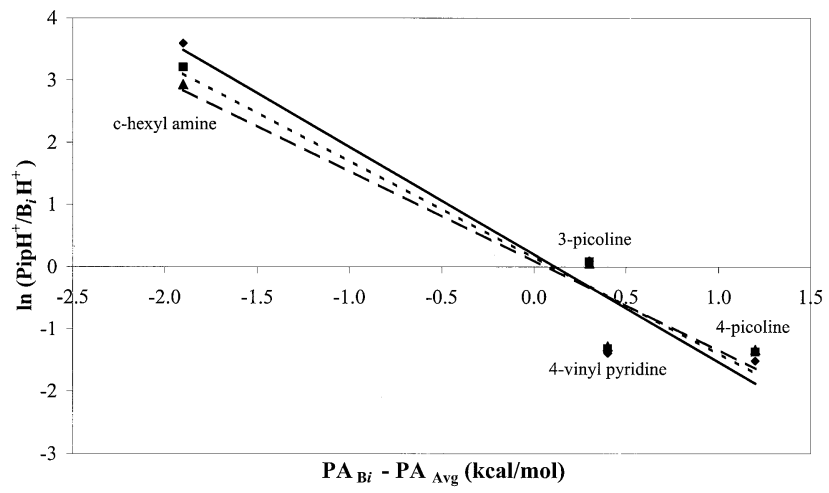

Figure 5. Plot of $\ln \left[\mathrm{PipH}^{+} / \mathrm{B}_{i} \mathrm{H}^{+}\right]$versus $\mathrm{PA}\left(\mathrm{B}_{i}\right)-\mathrm{PA}_{\text {avg }}$ at three different activation energies with best-fit lines. (Filled diamond, single line) $3 \mathrm{~V}$, (filled square, short-dashed line) $10 \mathrm{~V}$, and (filled triangle, long-dashed line) $17.5 \mathrm{~V}$ lab.

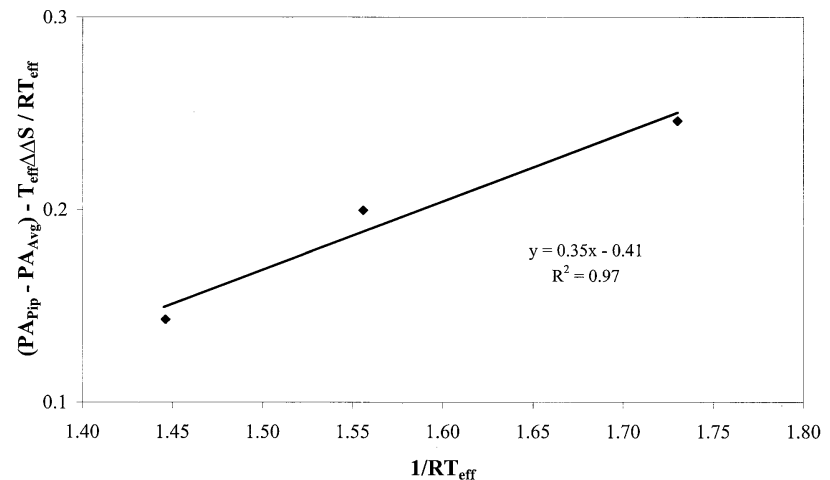

Figure 6. Plot $\left[\left(\mathrm{PA}_{\mathrm{Pip}}-\mathrm{PA}_{\mathrm{avg}}\right)-\mathrm{T}_{\text {eff }} \Delta \Delta \mathrm{S}\right] / \mathrm{RT}_{\mathrm{eff}}$ versus $1 / \mathrm{RT}_{\mathrm{eff}}$ for pipecolic acid.

bond between a hydrogen on the nitrogen atom and the carbonyl oxygen was determined to be the global minimum at all levels studied (III, Figure 8). The $\mathrm{AzeH}^{+}$ results are shown in Table 3.

The $298 \mathrm{~K}$ proton affinity for Aze was calculated using isodesmic reaction 1 with dimethyl amine as the reference base. The PA values from different levels of theory are

$$
\text { Aze }+\left(\mathrm{CH}_{3}\right)_{2} \mathrm{NH}_{2}{ }^{+} \rightarrow \mathrm{AzeH}^{+}+\left(\mathrm{CH}_{3}\right)_{2} \mathrm{NH}
$$

listed in Table 4 along with the calculated $\Delta S_{\text {base }}$ and derived gas-phase basicity values for Aze. The isodesmic approach using correlated methods (MP2 and B3LYP) gives proton affinities for Aze that are in good agreement with our experimental determination of $223.0 \mathrm{kcal} / \mathrm{mol}$. Uncertainties for the calculated proton affinities at these levels of theory are in the range of 2-3 $\mathrm{kcal} / \mathrm{mol}$.

Similar calculations were performed on neutral and protonated proline and pipecolic acid. Total energies, zero-point energies, 298 enthalpies, and total entropies for these species are listed in Tables 2 and 3. Proline has been the subject of several recent theoretical investigations [20, 21]. Our results are in accord with other theoretical predictions in terms of the lowest energy structures for neutral proline. The lowest energy struc-

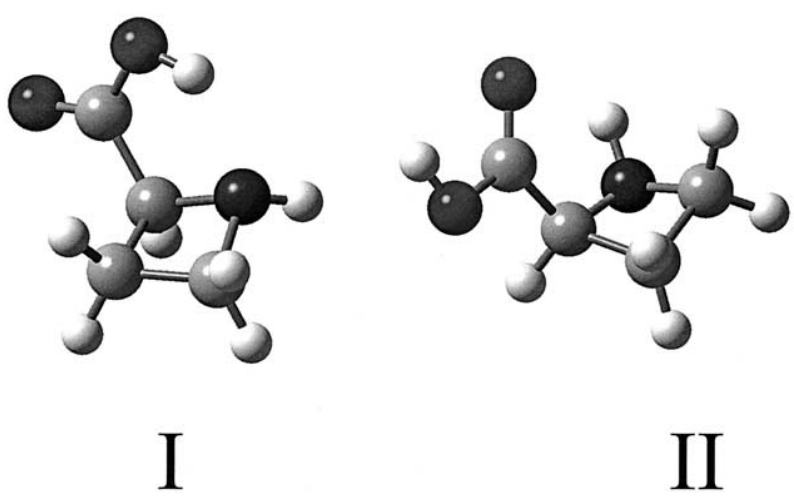

Figure 7. Optimized structures for Aze at the B3LYP $/ 6-311+\mathrm{G}^{*}$ level of theory. 
Table 2. Total electronic energies, zero point energies, and $298 \mathrm{~K}$ enthalpies (Hartrees) and total entropy (eu) for proline analogs and dimethyl amine

\begin{tabular}{|c|c|c|c|c|c|}
\hline Method & Structure $^{a}$ & $\mathrm{E}_{\mathrm{el}}$ & $\mathrm{ZPE}^{\mathrm{b}}$ & $\mathrm{H}_{298}{ }^{\mathrm{c}}$ & $S^{d}$ \\
\hline \multicolumn{6}{|l|}{ Pipecolic acid } \\
\hline $\mathrm{HF} / 6-31 \mathrm{G}^{*}$ & I & -437.80355 & 0.17246 & -437.62185 & 88.7 \\
\hline $\mathrm{HF} / 6-31 \mathrm{G} *$ & II & -437.80562 & 0.17173 & -437.62432 & 90.6 \\
\hline MP2/6-31G* & 1 & -439.09842 & 0.17305 & -438.91679 & 87.8 \\
\hline MP2/6-31G* & II & -439.09597 & 0.17218 & -438.91478 & 88.7 \\
\hline B3LYP/6-31G* & I & -440.47287 & 0.17230 & -440.29166 & 87.5 \\
\hline B3LYP/6-31G* & II & -440.47121 & 0.17143 & -440.29047 & 90.2 \\
\hline B3LYP/6-31+G* & I & -440.49131 & 0.17161 & -440.31071 & 88.0 \\
\hline B3LYP/6-31+G* & II & -440.49097 & 0.17084 & -440.31079 & 90.2 \\
\hline B3LYP/6-311+G* & I & -440.59096 & 0.17129 & -440.41068 & 88.0 \\
\hline B3LYP/6-311+G* & II & -440.59092 & 0.17057 & -440.41102 & 90.1 \\
\hline \multicolumn{6}{|l|}{ Proline } \\
\hline $\mathrm{HF} / 6-31 \mathrm{G} *$ & 1 & -398.76386 & 0.14350 & -398.61181 & 87.1 \\
\hline $\mathrm{HF} / 6-31 \mathrm{G}^{*}$ & II & -398.76541 & 0.14296 & -398.61365 & 89.5 \\
\hline MP2/6-31G* & I & -399.92542 & 0.14375 & -399.77379 & 83.9 \\
\hline $\mathrm{MP} 2 / 6-31 \mathrm{G}^{*}$ & II & -399.92399 & 0.14330 & -399.77250 & 85.8 \\
\hline B3LYP/6-31G* & I & -401.15371 & 0.14323 & -401.00231 & 85.9 \\
\hline B3LYP/6-31G* & II & -401.15181 & 0.14275 & -401.00066 & 86.7 \\
\hline B3LYP/6-31+G* & I & -401.17340 & 0.14274 & -401.02244 & 85.6 \\
\hline B3LYP/6-31+G* & II & -401.17068 & 0.14234 & -401.01990 & 87.0 \\
\hline B3LYP/6-311+G* & I & -401.26555 & 0.14252 & -401.11482 & 85.6 \\
\hline B3LYP/6-311+G* & II & -401.26321 & 0.14210 & -401.11264 & 87.3 \\
\hline \multicolumn{6}{|l|}{ Azetidine-2- $\mathrm{COOH}$} \\
\hline $\mathrm{HF} / 6-31 \mathrm{G} *$ & I & -359.69820 & 0.11448 & -359.57622 & 80.8 \\
\hline $\mathrm{HF} / 6-31 \mathrm{G} *$ & II & -359.70005 & 0.11404 & -359.57837 & 81.5 \\
\hline $\mathrm{MP} 2 / 6-31 \mathrm{G}^{*}$ & I & -360.72598 & 0.11396 & -360.60494 & 78.5 \\
\hline MP2/6-31G* & II & -360.72605 & 0.11374 & -360.60508 & 78.5 \\
\hline $\mathrm{MP} 2 / 6-31+\mathrm{G}^{*}$ & I & -360.75175 & 0.11345 & -360.63120 & 78.8 \\
\hline $\mathrm{MP} 2 / 6-31+\mathrm{G}^{*}$ & II & -360.75062 & 0.11296 & -360.63036 & 78.8 \\
\hline $\mathrm{MP} 2 / 6-311+\mathrm{G}^{*}$ & I & -360.89359 & 0.11416 & -360.77227 & 79.1 \\
\hline $\mathrm{MP} 2 / 6-311+\mathrm{G}^{*}$ & II & -360.89290 & 0.11377 & -360.77178 & 80.2 \\
\hline B3LYP/6-31G* & I & -361.80990 & 0.11372 & -361.68889 & 80.0 \\
\hline B3LYP/6-31G* & II & -361.80854 & 0.11322 & -361.68780 & 81.5 \\
\hline B3LYP/6-31+G* & I & -361.82900 & 0.11340 & -361.70829 & 80.1 \\
\hline B3LYP/6-31+G* & II & -361.82702 & 0.11281 & -361.70664 & 81.7 \\
\hline B3LYP/6-311+G* & I & -361.91341 & 0.11316 & -361.79289 & 80.1 \\
\hline B3LYP/6-311+G* & II & -361.91180 & 0.11266 & -361.79158 & 81.7 \\
\hline \multicolumn{6}{|l|}{$\left(\mathrm{CH}_{3}\right)_{2} \mathrm{NH}$} \\
\hline $\mathrm{HF} / 6-31 \mathrm{G}^{*}$ & - & -134.23885 & 0.09071 & -134.14271 & - \\
\hline MP2/6-31G* & - & -134.66530 & 0.09218 & -134.56793 & - \\
\hline $\mathrm{MP} 2 / 6-31+\mathrm{G}^{*}$ & - & -134.67482 & 0.09175 & -134.57786 & - \\
\hline $\mathrm{MP} 2 / 6-311+\mathrm{G}^{*}$ & - & -134.72395 & 0.09200 & -134.62668 & - \\
\hline B3LYP/6-31G* & - & -135.16285 & 0.09131 & -135.06624 & - \\
\hline B3LYP/6-31+G* & - & -135.17035 & 0.09102 & -135.07401 & - \\
\hline B3LYP/6-311+G* & - & -135.19888 & 0.09072 & -135.10282 & - \\
\hline
\end{tabular}

a See text for discussion of structures.

bDerived from scaled harmonic vibrational - frequencies; for scaling factors see reference [39].

${ }^{c} \mathrm{H}_{298}=\mathrm{E}_{\mathrm{el}}+\mathrm{ZPE}+\Delta \mathrm{ZPE}+5 / 2 \mathrm{RT} . \Delta \mathrm{ZPE}$ is derived from harmonic vibrational frequencies; for scaling factors see reference [39].

${ }^{d} S_{\text {trans }}$ and $S_{\text {rot }}$ taken from Gaussian output, $S_{\text {vib }}$ evaluated from scaled vibrational frequencies; for scaling factors see reference [39].

tures involve hydrogen bonding between the hydroxyl hydrogen and the nitrogen lone pair or between the carbonyl oxygen and an amino hydrogen, similar to structures I and II described above for Aze. The lowest energy structures for Pip are also of these forms. Protonated proline and pipecolic acid both adopt structures similar to III with a hydrogen bond between a hydrogen on the nitrogen and the carbonyl oxygen.
Isodesmic reactions with dimethyl amine as the reference base were used to generate predictions for the proton affinity for proline and pipecolic acid. These values are listed in Table 3. As with Aze, the correlated methods give good agreement with our experimental determinations of 224.9 and $225.6 \mathrm{kcal} / \mathrm{mol}$. We should mention that our derived PA for proline of 225.4 at the B3LYP $/ 6-311+G^{*}$ level does not agree with a recent 


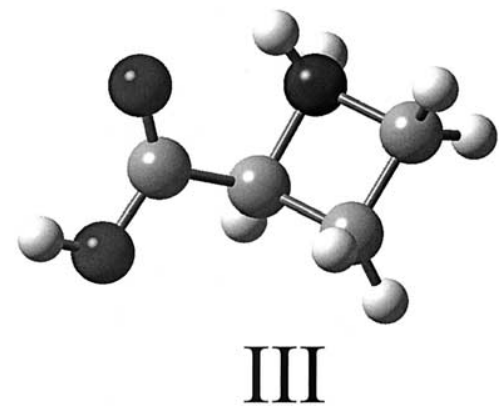

Figure 8. Optimized structure for $\mathrm{AzeH}^{+}$at the B3LYP/ $6-311+G^{*}$ level of theory.

theoretical study by Toscano and co-workers [21]. They calculate a $298 \mathrm{~K} \mathrm{PA}$ of $220.9 \mathrm{kcal} / \mathrm{mol}$ using B3LYP $/ 6-311++\mathrm{G}^{* *}$ calculations. Upon closer examination of the total electronic energies for proline and protonated proline given in their paper, it appears that an arithmetic error was made in the conversion of the 0 $\mathrm{K}$ energy difference to the $298 \mathrm{~K}$ proton affinity. Taking the total electronic energies for the lowest-energy structures for neutral and protonated proline from their paper gives a ZPE-corrected energy difference of 222.9 $\mathrm{kcal} / \mathrm{mol}$. Conversion to a $298 \mathrm{~K}$ requires the addition of (1) the difference in integrated vibrational heat capacity between neutral and protonated proline, (2) 3/2 RT for the integrated translational heat capacity of the proton, and (3) an additional RT for conversion of the energy difference to an enthalpy. Since the vibrational frequencies were not listed in the Toscano paper, we cannot evaluate the difference in integrated vibrational heat capacity between Pro and $\mathrm{ProH}+$ and therefore cannot convert their $0 \mathrm{~K}$ energy difference to a $298 \mathrm{~K} \mathrm{PA}$ directly. However, in our work, all $298 \mathrm{~K}$ enthalpies are larger than the $0 \mathrm{~K}$ energy differences. It appears as if the authors subtracted the thermal correction rather than adding it.

\section{Discussion}

\section{Comparison with Previous Results for Proline}

The recommended proton affinity and gas-phase basicity of proline according to the Lias compilation are 220.0 and $211.8 \mathrm{kcal} / \mathrm{mol}$ respectively [40]. The large discrepancy between our value and the recommended one was initially a cause for concern. Table 5 lists the various

Table 3. Total electronic energies, zero point energies, and $298 \mathrm{~K}$ enthalpies (Hartrees) and entropies (eu) for protonated proline analogs and protonated dimethyl amine

\begin{tabular}{|c|c|c|c|c|}
\hline Method & $\mathrm{E}_{\mathrm{el}}$ & $\mathrm{ZPE}^{\mathrm{a}}$ & $\mathrm{H}_{298}{ }^{\mathrm{b}}$ & $\mathrm{S}^{\mathrm{c}}$ \\
\hline \multicolumn{5}{|l|}{$\overline{\mathrm{PipH}^{+}}$} \\
\hline $\mathrm{HF} / 6-31 \mathrm{G}^{*}$ & -438.18554 & 0.18660 & -437.98941 & 90.2 \\
\hline $\mathrm{MP} 2 / 6-31 \mathrm{G}^{*}$ & -439.47413 & 0.18697 & -439.27827 & 87.2 \\
\hline B3LYP/6-31G* & -440.85040 & 0.18640 & -440.65476 & 89.2 \\
\hline $\mathrm{B} 3 \mathrm{LYP} / 6-31+\mathrm{G} *$ & -440.86134 & 0.18598 & -440.66608 & 89.5 \\
\hline $\mathrm{B} 3 \mathrm{LYP} / 6-311+\mathrm{G} *$ & -440.96152 & 0.18579 & -440.76646 & 89.5 \\
\hline \multicolumn{5}{|l|}{$\mathrm{ProH}^{+}$} \\
\hline $\mathrm{HF} / 6-31 \mathrm{G} *$ & -399.14487 & 0.15762 & -398.97856 & 87.5 \\
\hline $\mathrm{MP} 2 / 6-31 \mathrm{G}^{*}$ & -400.30033 & 0.15753 & -400.13464 & 85.0 \\
\hline B3LYP/6-31G* & -401.53197 & 0.15729 & -401.36638 & 85.3 \\
\hline $\mathrm{B} 3 \mathrm{~L} Y \mathrm{P} / 6-31+\mathrm{G}^{*}$ & -401.54258 & 0.15705 & -401.37721 & 85.5 \\
\hline B3LYP/6-311+G* & -401.63484 & 0.15692 & -401.46952 & 86.0 \\
\hline \multicolumn{5}{|l|}{$\mathrm{AzeH}^{+}$} \\
\hline $\mathrm{HF} / 6-31 \mathrm{G} *$ & -360.07483 & 0.12803 & -359.93893 & 84.1 \\
\hline $\mathrm{MP} 2 / 6-31 \mathrm{G}^{*}$ & -361.09585 & 0.12757 & -360.96087 & 80.8 \\
\hline $\mathrm{MP} 2 / 6-31+\mathrm{G}^{*}$ & -361.11263 & 0.12703 & -360.97818 & 80.6 \\
\hline $\mathrm{MP} 2 / 6-311+\mathrm{G}^{*}$ & -361.25552 & 0.12812 & -361.11998 & 80.7 \\
\hline B3LYP/6-31G* & -362.18258 & 0.12746 & -362.04750 & 82.6 \\
\hline $\mathrm{B} 3 \mathrm{~L} Y \mathrm{P} / 6-31+\mathrm{G}^{*}$ & -362.19302 & 0.12726 & -362.05813 & 82.3 \\
\hline $\mathrm{B} 3 \mathrm{LYP} / 6-311+\mathrm{G} *$ & -362.27795 & 0.12724 & -362.14307 & 82.4 \\
\hline \multicolumn{5}{|l|}{$\left(\mathrm{CH}_{3}\right)_{2} \mathrm{NH}$} \\
\hline $\mathrm{HF} / 6-31 \mathrm{G} *$ & -134.61353 & 0.10594 & -134.50204 & - \\
\hline $\mathrm{MP} 2 / 6-31 \mathrm{G}^{*}$ & -135.03668 & 0.10711 & -134.92425 & - \\
\hline $\mathrm{MP} 2 / 6-31+\mathrm{G}^{*}$ & -135.03978 & 0.10680 & -134.92765 & - \\
\hline $\mathrm{MP} 2 / 6-311+\mathrm{G}^{*}$ & -135.08943 & 0.10737 & -134.97669 & - \\
\hline B3LYP/6-31G* & -135.53403 & 0.10660 & -135.42199 & - \\
\hline $\mathrm{B} 3 \mathrm{~L} Y \mathrm{P} / 6-31+\mathrm{G} *$ & -135.53559 & 0.10657 & -135.42362 & - \\
\hline $\mathrm{B} 3 \mathrm{LYP} / 6-311+\mathrm{G} *$ & -135.56387 & 0.10628 & -135.45215 & - \\
\hline
\end{tabular}

aDerived from scaled harmonic vibrational frequencies; for scaling factors see reference [39].

${ }^{b} H_{298}=E_{e l}+Z P E+\Delta Z P E+5 / 2 R T . \Delta Z P E$ is derived from harmonic vibrational frequencies; for scaling factors see reference [39].

${ }^{\mathrm{c}} \mathrm{S}_{\text {trans }}$ and $\mathrm{S}_{\text {rot }}$ taken from Gaussian output, $\mathrm{S}_{\mathrm{vib}}$ evaluated from scaled vibrational frequencies; for scaling factors see reference [39]. 
Table 4. Derived thermochemical values for proline analogs

\begin{tabular}{llcl}
\hline Method & $\begin{array}{l}\text { Proton } \\
\text { affinity }^{\mathrm{a}}\end{array}$ & $\Delta \mathrm{S}_{\text {base }}(\mathrm{eu})^{\mathrm{b}}$ & $\Delta \mathrm{GB}$ \\
\hline \hline Pipecolic acid & & & \\
HF/6-31G* & 225.6 & 26.7 & 217.7 \\
MP2/6-31G* & 225.2 & 26.6 & 217.3 \\
B3LYP/6-31G* & 226.6 & 24.3 & 219.4 \\
B3LYP/6-31+G* & 225.6 & 24.5 & 218.3 \\
B3LYP/6-311+G* & 226.0 & 24.5 & 218.7 \\
\hline & & & \\
Proline & & & \\
HF/6-31G* & 225.5 & 28.0 & 217.2 \\
MP2/6-31G* & 224.8 & 24.9 & 217.4 \\
B3LYP/6-31G* & 227.2 & 26.7 & 219.3 \\
B3LYP/6-31+G* & 225.2 & 26.2 & 217.4 \\
B3LYP/6-311+G* & 225.4 & 25.6 & 217.8 \\
\hline & & & \\
Azetidine-2-COOH & & & \\
HF/6-31G* & 222.8 & 23.4 & 215.8 \\
MP2/6-31G* & 221.7 & 23.7 & 214.6 \\
MP2/6-31+G* & 220.2 & 24.2 & 213.0 \\
MP2/6-311+G* & 220.6 & 24.4 & 213.3 \\
B3LYP/6-31G* & 223.8 & 23.4 & 216.8 \\
B3LYP/6-31+G* & 222.1 & 23.8 & 215.0 \\
B3LYP/6-311+G* & 222.2 & 23.7 & 215.4 \\
\hline
\end{tabular}

aDerived from isodesmic reation 1.

${ }^{b} \mathrm{~S}(\mathrm{M})+\mathrm{S}\left(\mathrm{H}^{+}\right)-\mathrm{S}\left(\mathrm{MH}^{+}\right)$.

experimental determinations of the PA and GB for proline. The recommended value from the NIST website for the proton affinity of proline is taken from the kinetic method determination of Harrison and co-workers [28] with an adjustment for the change in the

Table 5. Experimental proton affinities and gas phase basicities $(\mathrm{kcal} / \mathrm{mol})$ for proline

\begin{tabular}{ccc}
\hline Gas phase basicity & $\begin{array}{c}\text { Proton } \\
\text { affinity }\end{array}$ & Reference \\
\hline \hline PA measurements & & \\
$217.3 \pm 1.0^{\text {ab }}$ & $224.9 \pm 1.6$ & This work \\
$211.8^{\mathrm{c}}$ & 220.0 & 5 \\
$213.9^{\mathrm{c}}$ & 222.1 & 5 \\
$211.9^{\mathrm{d}}$ & 219.9 & 32 \\
$215.9^{\mathrm{d}}$ & 223.9 & 31 \\
\hline & & \\
GB measurements & $222.6-223.0^{\mathrm{d}}$ & 44 \\
$214.6-215.0$ & $223.1-227.4^{\mathrm{d}}$ & 42 \\
$215.1-219.4$ & $225.7^{\mathrm{d}}$ & 43 \\
217.7 & $223.0^{\mathrm{d}}$ & 45 \\
215.0 & $222.3^{\mathrm{d}}$ & 45 \\
214.3 & $214.7^{\mathrm{d}}$ & 46 \\
206.7 & & \\
\hline & & 35 \\
Evaluated quantities & 220.0 & 40 \\
211.8 & 222.1 & This work \\
214.3 & $224 \pm \mathbf{2}$ &
\end{tabular}

altalicized entries are derived from the measured value (normal font) by addition/subtraction of $\mathrm{T} \Delta \mathrm{S}_{\text {base. }}$

${ }^{\mathrm{b}} \Delta \mathrm{S}_{\text {base }}=25.6$ eu derived from B3LYP/6-311+G* calculations.

${ }^{\mathrm{c}} \Delta \mathrm{S}_{\text {base }}=27.7 \mathrm{eu}$ from reference [40].

${ }^{\mathrm{d}} \Delta \mathrm{S}_{\text {base }}=26.7$ eu; average of entropies given in footnotes $\mathrm{b}$ and $\mathrm{c}$. absolute proton affinity scale [43]. Harrison and coworkers measured proton affinities for proline of 218.5 and $220.5 \mathrm{kcal} / \mathrm{mol}$ using ethyl amine and dimethyl amine as reference bases. Of the two different values, Hunter and Lias chose to adjust the lower of the two, taking into account the $1.5 \mathrm{kcal} / \mathrm{mol}$ increase in the absolute PA of ethylamine since 1993 [40]. In contrast, in 1997, Harrison and co-workers reevaluated the proton affinities and gas phase basicities for all 20 amino acids and chose to adjust the higher of his two determinations to account for the $1.6 \mathrm{kcal} / \mathrm{mol}$ increase in the absolute PA of dimethyl amine, giving a recommended $\mathrm{PA}$ of $222.1 \mathrm{kcal} / \mathrm{mol}$ [44].

Since the Hunter and Lias compilation, there have been two additional measurements of the PA of proline by Mirza et al. [23] and by Tabet and co-workers [22]. Mirza et al. report a PA of $219.9 \mathrm{kcal} / \mathrm{mol}$ based on the extended kinetic method described above. This work used amino acids as reference bases, with proton affinities taken from the Bojeson scale [45], however, the reference PAs were not adjusted to reflect the change in absolute PA scale [43]. This value is therefore probably too low. Tabet and co-workers have also recently remeasured the proton affinities of the 20 PAAs using the extended kinetic method [22]. Their study also used amino acids as reference bases, but only those that have PAs which are consistent across several different PA scales. Using Ser, Leu, Thr, Met, and Trp as reference bases, Tabet and co-workers determined the PA of proline to be $223.9 \mathrm{kcal} / \mathrm{mol}$.

The Harrison determination is the only proton affinity listed in the Lias compilation; all other experiments were for the gas-phase basicity of proline. The recommended value of $211.8 \mathrm{kcal} / \mathrm{mol}$ is derived from the PA of Harrison using an entropy difference of -1.7 entropy units between Pro and $\mathrm{ProH}^{+}\left(\Delta \mathrm{S}_{\text {base }}=27.7 \mathrm{cal} \mathrm{mol}^{-1}\right.$ $\mathrm{K}^{-1}$ ) [40]. Our B3LYP /6-311+ $\mathrm{G}^{*}$ calculations predict a difference in entropy of $0.4 \mathrm{eu}$, which leads to a $\Delta \mathrm{S}_{\text {base }}$ for proline of $25.6 \mathrm{cal} \mathrm{mol}^{-1} \mathrm{~K}^{-1}$. Combining this quantity with our experimental PA of $224.9 \pm 1.6$ $\mathrm{kcal} / \mathrm{mol}$ leads to a prediction of GB (Pro) of $217.3 \pm 1.9$ $\mathrm{kcal} / \mathrm{mol}$, where the uncertainty includes an additional $1 \mathrm{kcal} / \mathrm{mol}$ uncertainty in $\Delta \mathrm{S}$.

Our derived GB value is in excellent agreement with the ICR bracketing study of Amster and co-workers [46] as well as the ICR equilibrium studies of Locke and McIver [47], while it is somewhat higher than a recent bracketing study of Cassady and co-workers [48] and the equilibrium studies of Moetner(Mautner) and Hunter [49]. An examination of Table 5 indicates that the determination of Yamdagni and Kebarle is probably too low [50]. In light of the fact that all but one of the measured GBs listed in the Lias compilation are greater than $214 \mathrm{kcal} / \mathrm{mol}$, we recommend that the accepted value for GB (Pro) be changed to $216 \pm 2 \mathrm{kcal} / \mathrm{mol}$, a value that encompasses all of the GB determinations except Kebarle's.

To aid in comparing PA data, we have converted these GB data in Table 5 to PAs by adding a $\Delta S$ term of 
$26.7 \mathrm{cal} \mathrm{mol}^{-1} \mathrm{~K}^{-1}$, the average of our computational prediction and the entropy given in the Lias compilation [40]. As with GB (Pro), the recommended PA for proline is probably too low, and we recommend a value of $224 \pm 2 \mathrm{kcal} / \mathrm{mol}$. This encompasses our value and Tabet's recent determination [22], as well as Harrison's adjusted proton affinity [51], and all of the PAs obtained from conversion of measured GB data.

\section{Agreement Between Theory and Experiment}

One of the goals of this research was to establish a level of theory that gives reasonable agreement with our experimental results. In the future we will be investigating amino acids with multiple basic sites. It will be imperative to have a theoretical prediction for the relative basicity of the different sites of these molecules so that we know which site we are accessing in our kinetic method experiment. We will probably not be able to use the most reliable of the currently available theoretical procedures, the compound methods G2 [52], G3[53], CBS-Q [54], and CBS-APNO [55] because of the large size of these amino acids. We will most likely need to resort to lower level MP or DFT methods to get theoretical predictions for our experimental quantities. DFT has been used extensively to calculate the proton affinity of a variety of molecules [56-61] including amino acids [21, 62, 63]. Provided that a suitable basis set is used, DFT has been shown to give reasonable agreement with experimental results and higher level calculations in many cases.

The present study reveals that both MP2 and B3LYP methods reproduce our experimental data. Somewhat surprisingly, the $\mathrm{HF} / 6-31 \mathrm{G}^{*}$ calculations also give good agreement with our experimental results for the three analogs. For Aze, we could investigate the effects of basis set size and the addition of diffuse functions on the derived proton affinities. Increasing basis set size from double zeta to triple zeta results in slightly worse agreement at the MP2 level whereas it has no effect at the B3LYP level. Addition of diffuse functions lowers the calculated PAs by approximately $1.5 \mathrm{kcal} / \mathrm{mol}$ for both MP2 and B3LYP methods. Based on the comparisons using the $6-31 G^{*}$ basis set, the B3LYP method gives proton affinities that are 1.5 to $2 \mathrm{kcal} / \mathrm{mol}$ larger than those from the MP2 method. As the uncertainties in these calculations are probably on the order of \pm 2 $\mathrm{kcal} / \mathrm{mol}$, all of the levels of theory give satisfactory agreement with our experimental determination.

For the larger analogs, the MP2/6-311+ $\mathrm{G}^{*}$ calculations were beyond the computational power of our desktop computers. This will also be the case for some of the larger NPAAs, such as arginine analogs, which we wish to investigate in the future. Density functional methods will allow us to study these molecules using relatively large basis sets. Table 4 reveals that for proline and pipecolic acid, B3LYP gives excellent agreement with our experimental results at all three basis sets used. In terms of computational effectiveness, we will use the B3LYP $/ 6-31+G^{*}$ combination for further studies.

\section{Thermochemical Trends}

The primary goal of this study was to determine the effect of ring size on the proton affinity of these amino acids. Proton affinities for the homologous series of heterocyclic nitrogen bases, azetidine, pyrrolidine, and piperidine have been determined by several groups[40] and have recently been studied by high-level theoretical calculations [64]. The Lias compilation recommends values of $224.5,226.6$, and $228 \mathrm{kcal} / \mathrm{mol}$ for the $4-$, 5-, and 6-membered ring nitrogen heterocycles. The monotonic increase in PA $(223.0,224.9,225.6 \mathrm{kcal} / \mathrm{mol})$ is also seen in the amino acid analogs, albeit with smaller differences. Replacing the hydrogen alpha to the amine with a $\mathrm{COOH}$ group to form the amino acid results in a decrease in PA of ca. $1.5 \mathrm{kcal} / \mathrm{mol}$. This is in good agreement with Harrison's observations in his proton affinity review [44].

Finally, the extended kinetic method allows for the separation of the contributions of enthalpy and entropy to the dissociation of a proton-bound dimer. The entropy obtained from the $y$-intercept of plot 2 is the average difference in activation entropy between the proline analog channel and the reference base channel. All of our reference bases are primary or secondary amines that should not form intramolecular hydrogen bonds upon protonation. Consequently, the activation entropy difference between the proline analogs (all secondary amines) and the reference bases should be small. The measured values of $\Delta S$ are 3.4, 2.0, and $0.8 \mathrm{eu}$ for Aze, Pro, and Pip respectively. The monotonic decrease in entropy differences is of note. These entropies are much smaller than those that have been measured when either the protonated reference bases or the protonated unknown can form intramolecular hydrogen bonds [23]. For example, we have been studying the lysine analogs, Lys, Orn, 2,4-diaminobutanoic acid, and 2,3-diaminopropanoic acid using the extended kinetic method [65]. Preliminary studies give entropy differences on the order of 10-15 eu, much larger than the ones measured here. Therefore it appears that the extended kinetic method can be used as a probe for intramolecular hydrogen bonding.

\section{References}

1. Bell E. A. Non-Protein Amino Acids in Plants. Encylc. Plant. Phys. 1975, 403.

2. Evans, C. S.; Bell, E. A. "Uncommon" Amino Acids in 64 Species of Caesalpinieae. Phytochemistry 1978, 17, 1127.

3. Rubenstein, E. Biological Effects of and Clinical Disorders Caused by Nonprotein Amino Acids. Medicine 2000, 79, 80.

4. Rosenthal, G. A. The Biochemical Basis for the Deleterious Effects of L-Canavanine. Phytochemistry 1991, 30, 1055.

5. Rosenthal, G. A.; Janzen, D. H. Avoidance of Non-Protein Amino Acid Incorporation into Protein by the Seed Predator Caryede brasiliensis (Bruchidae). J. Chem. Ecol. 1983, 9, 1353. 
6. Melangeli, C.; Rosenthal, G. A.; Dalman, D. L. The Biochemical Basis for L-Canavanine Tolerance by the Tobacco Budworm Heliothis virescens (Noctuidae). Proc. Nat. Acad. Sci., U.S.A 1997, 94, 2255.

7. Rosenthal, G. A. The Biological Effects and Mode of Action of L-Canavanine, a Structural Analogue of L-Arginine. Qu. Rev. Biol. 1977, 52, 155.

8. Boyar, A.; Marsh, R. E. L-Canavanine, A Paradigm for the Structures of Substituted Guanidines. J. Am. Chem. Soc. 1982, 104, 1995.

9. Carvajal, N.; Torres, C.; Uribe, E.; Salas, M. Interaction of Arginase with Metal Ions: Studies of the Enzyme From Human Liver and Comparison with Other Arginases. Comp. Biochem. Physiol. 1995, 112, 153

10. Deming, T. J.; Fournier, M. J.; Mason, T. L.; Tirrell, D. A. Structural Modification of a Periodic Polypeptide Through Biosynthetic Replacement of Proline with Azetidine-2-carboxylic Acid. Macromolecules 1996, 29, 1442.

11. Copeland, T. D.; Wondrak, E. M.; Tozser, J.; Roberts, M. M.; Oroszian, S. Substitution of Proline With Pipecolic Acid at the Scissile Bond Converts a Peptide Substrate of HIV Proteinase into a Selective Inhibitor. Biochem. Biophys. Res. Comm. 1990, 169,310

12. Kunii, Y.; Otsuka, M.; Kashino, S.; Takeuchi, H.; Ohmori, S. 4-Hydroxypipecolic Acid and Pipecolic Acid in Acacia Species: Their Determination by HPLC, Its Application to Leguminous Plants, and Configuration of 4-Hydroxypipecolic. Acid. J. Agric. Food Chem. 1996, 44, 483.

13. Maison, W.; Lützen, A.; Kosten, M.; Schlemminger, I.; Westerhoff, O.; Saak, W.; Martens, J. Multicomponent Synthesis of Tripeptides Containing Pipecolic Acid Derivatives: Selective Induction of cis- and trans-imide Bonds into Peptide Backbones. J. Chem. Soc. Perkin Trans. 2000, 1, 1867.

14. Carrington, M. J.; Fornieri, D.; Bartlet, C. P.; Heale, G.; Levene, C. I. Biochemical and Ultrastructural Study of the Effects of Proline Analogues on Collagen Synthesis in 3T6 Fibroblasts. J. Pharm. Pharmacol. 1985, 37, 794.

15. Wu, W.; Raleigh, D. P. Conformational Heterogeneity About Pipecolic Acid Peptide Bonds: Conformational Thermodynamic and Kinetic Aspects. J. Org. Chem. 1998, 63, 6689.

16. Zagari, A.; Nemethy, G.; Scheraga, H. A. The Effect of the L-Aze Residue on Protein Conformation. I. Conformations of the Residue and of Dipeptides. Biopolymers 1990, 30, 951.

17. Zagari, A.; Nemethy, G.; Scheraga, H. A. The Effect of LAzetidine-2-carboxylic Acid Residue on Protein Conformation. II. Homopolymers and Copolymers. Biopolymers 1990, 30, 961.

18. Zagari, A.; Nemethy, G.; Scheraga, H. A. The Effect of LAzetidine-2-Carboxylic Acid Residue on Protein Conformation. III. Collagen-like Polytripeptides. Biopolymers 1990, 30, 967.

19. Zagari, A.; Palmer, K. A.; Gibson, K. D.; Nemethy, G.; Scheraga, H. A. The Effect of 1-Azeditide-2-Carboxylic Acid on Protein Conformation. IV. Local Substitutions in the Collagen Triple Helix. Biopolymers 1994, 34, 51.

20. Maksic, Z. B.; Kovacevic, B. Towards the Absolute Proton Affinity of $20 \alpha$-Amino Acids. Chem. Phys. Lett. 1999, 307, 497.

21. Marino, T.; Russo, N.; Tocci, E.; Toscano, M. Density Functional Theory Computations of the Proton Affinity and Gasphase Basicity of Proline. J. Mass Spectrom. 2001, 36, 301.

22. Afonso, C.; Modeste, F.; Breton, P.; Fournier, F.; Tabet, J. C. Proton Affinities of the Commonly Occurring L-Amino Acids by Using Electrospray Ionization-Ion Trap Mass Spectrometry. Eur. J. Mass Spectrom. 2000, 6, 443.

23. Mirza, S. P.; Prabhaker, S.; Vairamani, M. Estimation of Proton Affinity of Proline and Tryptophan Under Electrospray Ion- ization Conditions Using the Extended Kinetic Method. Rapid Comm. Mass Spectrom. 2001, 15, 957.

24. Cooks, R. G.; Kruger, T. L. Intrinsic Basicity Determinations Using Metastable Ions. J. Am. Chem. Soc. 1977, 99, 1279.

25. McLuckey, S. A.; Cameron, D.; Cooks, R. G. Proton Affinities from Dissociation of Proton-Bound Dimers. J. Am Chem. Soc. 1981, 103, 1313.

26. O'Hair, R. A. J.; Bowie, J. H.; Gronert, S. Gas-Phase Acidities of the $\alpha$-Amino Acids. Int. J. Mass Spectrom. Ion Processes 1992, 117, 23.

27. Cheng, X.-H.; Wu, Z.; Fenselau, C. Collision Energy Dependence of Proton-Bound Dimer Dissociation: Entropy Effects, Proton Affinities and Intramolecular Hydrogen Bonding of Protonated Peptides. J. Am. Chem. Soc. 1993, 115, 4884.

28. Li, X.; Harrison, A. G. A Kinetic Approach to the Proton Affinity of Amine Bases. Org. Mass Spectrom. 1993, 28, 366.

29. Cooks, R. G.; Patrick, J. S.; Kotiaho, T.; McLuckey, S. A. Thermochemical Determinations by the Kinetic Method. Mass Spectrom. Rev. 1994, 18, 287.

30. Wu, Z.; Fenselau, C. Gas Phase Basicities and Proton Affinities of Lysine and Histidine Measured from the Dissociation of Proton-Bound Dimers. Rapid Commun. Mass Spectrom. 1994, 8 , 777.

31. Cerda, B. A.; Wesdemiotis, C. $\mathrm{Li}+, \mathrm{Na}+$, and $\mathrm{K}+$ Binding to the DNA and RNA Nucleobases. Bond Energies and Attachment Sites from the Dissociation of Metal Ion-Bound Heterodimers. J. Am. Chem. Soc. 1996, 118, 11884.

32. Armentrout, P. B. Entropy Measurements and the Kinetic Method: A Statistically Meaningful Approach. J. Am. Soc. Mass Spectrom. 2000, 11, 371.

33. Frisch, M. J.; Trucks, G. W.; Schlegel, H. B.; Scuseria, G. E.; Robb, M. A.; Cheeseman, J. R.; Zakrzewski, V. G.; Montgomery, J. A.; Stratmann, R. E.; Burant, J. C.; Dapprich, S.; Millam, J. M.; Daniels, A. D.; Kudin, K. N.; Strain, M. C.; Farkas, O.; Tomasi, J.; Barone, V.; Cossi, M.; Cammi, R.; Mennucci, B.; Pomelli, C.; Adamo, C.; Clifford, S.; Ochterski, J.; Petersson, G. A.; Ayala, P. Y.; Cui, Q.; Morokuma, K.; Malick, D. K.; Rabuck, A. D.; Raghavachari, K.; Foresman, J. B.; Cioslowski, J.; Ortiz, J. V.; Baboul, A. G.; Stefanov, B. B.; Liu, G.; Liashenko, A.; Piskorz, P.; Komaromi, I.; Gomperts, R.; Martin, R. L.; Fox, D. J.; Keith, T.; Al-Laham, M. A.; Peng, C. Y.; Nanayakkara, N.; Gonzalez, C.; Challacombe, M.; Gill, P. M. W.; Johnson, B.; Chen, W.; Wong, M. W.; Andres, J. L.; Head-Gordon, M.; Replogle, E. S.; Pople, J. A. Gaussian 98, Revision A.7. Gaussian, Inc: Pittsburgh, 1998.

34. Hehre, W. J.; Radom, L.; Schleyer, P. V. R.; Pople, J. A. Ab initio Molecular Orbital Theory. Wiley and Sons: New York, 1986.

35. Parr, R. G.; Yang, W. Density Functional Theory of Atoms and Molecules. Oxford University Press: New York, 1989.

36. Becke, A. D. Density-Functional Exchange-Energy Approximation with Correct Asymptotic Behavior. Phys. Rev. A 1988, 38, 3098.

37. Becke, A. D. Density-Functional Thermochemistry. III. The Role of Exact Exchange. J. Chem. Phys. 1993, 98, 5648.

38. Lee, C.; Yang, W.; Parr, R. G. LYP Correlation Functional. Phys. Rev. B 1988, 37, 785.

39. Scott, A. P.; Radom, L. Harmonic Vibrational Frequencies: An Evaluation of Hartree-Fock, Moeller-Plesset, Quadratic Configuration Interaction, Density Functional Theory, and Semiempirical Scale Factors. J. Phys. Chem. 1996, 100, 16502.

40. Hunter, E. P.; Lias, S. G. Evaluated Gas Phase Basicities and Proton Affinities of Molecules: An Update. J. Phys. Chem. Ref. Data 1998, 27, 3.

41. Taft, R. W. Protonic Acidities and Basicities in the Gas Phase and in Solution: Substituent and Solvent Effects. Prog. Phys. Org. Chem. 1983, 14, 248. 
42. Aue, D. H.; Bowers, M. T. . Gas Phase Ion Chemistry, Vol II. Academic Press: New York, 1979.

43. Szulejko, J. E.; McMahon, T. B. Progress Toward an Absolute Gas-Phase Proton Affinity Scale. J. Am. Chem. Soc. 1993, 115, 7839.

44. Harrison, A. G. The Gas Phase Basicity and Proton Affinities of Amino Acids and Peptides. Mass Spectrom. Rev. 1997, 16, 201.

45. Bojesen, G.; Breindahl, T. On the Proton Affinity of Some $\alpha$-Amino Acids and the Theory of the Kinetic Method. J. Chem. Soc. Perkins Trans. 2 1994, 2, 1029.

46. Gorman, G. S.; Spier, J. P.; Turner, C. A.; Amster, I. J. Proton Affinities of the twenty Common $\alpha$-Amino Acids. J. Am. Chem. Soc. 1992, 114, 3986.

47. Locke, M. J.; McIver, R. T., Jr. Effect of Solvation on the Acid/Base Properties of Glycine. J. Am. Chem. Soc 1983, 105, 4226.

48. Ewing, N. P.; Zhang, X.; Cassady, C. J. Determination of the Gas Phase Basicities of Proline and its Di- and Tri-Peptides with Glycine: The Enhanced Basicity of Prolylproline. J. Mass Spectrom. 1996, 31, 1345.

49. Meotner(Mautner), M.; Hunter, E. P.; Field, F. H. Ion Thermochemistry of Low Volatility Compounds in the Gas Phase. I. Intrinsic Basicities of $\alpha$-Amino Acids. J. Am. Chem. Soc. 1979, 101, 686.

50. Yamdagni, R.; Kebarle, P. Intrinsic Acidities of $\alpha-, \beta-, \gamma$-Chlorosubstituted Aliphatic Acids from Gas Phase Equilibrium Measurements. J. Am. Chem. Soc. 1973, 95, 3504.

51. Harrison, A. G. The Gas Phase Basicities and Proton Affinities of Amino Acids and Peptides. Mass Spectrom. Rev. 1997, 16, 201.

52. Curtiss, L. A.; Raghavachari, K.; Trucks, G. W.; Pople, J. A. Gaussian-2 Theory for Molecular Energies of First- and Second-Row Compounds. J. Chem. Phys. 1991, 94, 7221.

53. Baboul, A. G.; Curtiss, L. A.; Redfern, P. C.; Raghavachari, K. Gaussian-3 Theory Using Density Functional Geometries and Zero-Point Energies. J. Chem. Phys. 1999, 110, 7650.
54. Ochterski, J. W.; Petersson, G. A.; Montgomery, J. A., Jr. A Complete Basis Set Model Chemistry. V. Extension to Six or More Heavy Atoms. J. Chem. Phys. 1996, 104, 2598.

55. Montgomery, J. A., Jr.; Ochterski, J. W.; Petersson, G. A. A Complete Basis Set Model Chemistry. IV. An Improved Atominc Pair Natural Orbital Method. J. Chem. Phys. 1994, 101, 5900.

56. Merrill, G. N.; Kass, S. R. Caluclated Gas Phase Acidities Using Density Functional Theory: Is it Reliable? J. Phys. Chem. 1996, 100, 17465.

57. Sauers, R. R. A Computational Study of Proton and Electron Affinites. Tetrahedron 1999, 55, 10013.

58. Jursic, B. Density Functional Theory and Complete Basis Set $\mathrm{Ab}$ initio Evaluation of Proton Affinity for Some Selected Chemical Systems. J. Mol. Struct. (THEOCHEM) 1999, 487, 193.

59. Rasmussen, D. R.; Radom, L. Hemispiroalkaplanes: Hydrocarbon Cage Systems with a Pyramidal-Teracoordinate Carbon Atom and Remarkable Basicity. Eur. J. Chem. 2000, 6, 2470.

60. Turecek, F. Proton Affinity of Peroxyacetyl Nitrate. A Computational Study of Topical Proton Affinities. J. Mass Spectrom. 2000, 35, 1351.

61. Wolken, J. K.; Turecek, F. Proton Affinity of Uracil. A Computational Study of Protonation Sites. J. Am. Soc. Mass Spectrom. 2000, 11, 1065.

62. Baeten, A.; De Proft, F.; Geerlings, P. Proton Affinity of Amino Acids: Their Interpretation with Density Functional TheoryBased Descriptors. Int. J. Quantum Chem. 1996, 60, 931.

63. Sun, W.; Kinsel, G. R.; Marynick, D. S. Computational Estimates of the Gas-Phase Basicity and Proton Affinity of Glutamic Acid. J. Phys. Chem. A 1999, 103, 4113.

64. Ball, D. W.; Vayner, E. Ab initio and Density Functional Optimized Structures, Proton Affinities, and Heats of Formation for Aziridine, Azetidine, Pyrrolidine, and Piperidine. J. Mol. Struct. (THEOCHEM) 2000, 496, 175.

65. Schroeder O. E., Poutsma, J. C. to be published. 